\title{
Commercialization in Innovation Management Defining the Concept and a Research Agenda
}

\author{
Sløk-Madsen, Stefan Kirkegaard ; Ritter, Thomas; Sornn-Friese, Henrik
}

Document Version

Final published version

Publication date:

2017

\section{License \\ CC BY-NC-ND}

Citation for published version (APA):

Sløk-Madsen, S. K., Ritter, T., \& Sornn-Friese, H. (2017). Commercialization in Innovation Management:

Defining the Concept and a Research Agenda. Paper presented at 77th Annual meeting of the Academy of Management, Atlanta, Georgia, United States.

Link to publication in CBS Research Portal

\section{General rights}

Copyright and moral rights for the publications made accessible in the public portal are retained by the authors and/or other copyright owners and it is a condition of accessing publications that users recognise and abide by the legal requirements associated with these rights.

Take down policy

If you believe that this document breaches copyright please contact us (research.lib@cbs.dk) providing details, and we will remove access to the work immediately and investigate your claim. 


\title{
Commercialization in Innovation Management: \\ Defining the Concept and a Research Agenda
}

\begin{abstract}
For any firm, the ultimate purpose of new product development is the commercialization of the new offerings. Despite its regular use in the product innovation and general management science literature, commercialization is only loosely defined and applied. This lack of conceptual clarity about the processes at the interface between product development and customer application is noteworthy as it hinders the theoretical development of the field. In this paper, we explore how research has advanced our understanding of commercialization in product innovation over a 30 year period by mapping different definitions and interpretations of commercialization. We offer a process-oriented definition of commercialization that is theoretically founded in the capabilitybased view of the firm. We also outline an agenda for future theoretical development and empirical research on commercialization aimed at advancing our understanding of the concept.
\end{abstract}

\section{Keywords:}

Commercialization, product development, innovation 


\section{Commercialization in Innovation Management: \\ Defining the Concept and a Research Agenda}

When an organization commits part of its inherently limited resources to innovative endeavors, it expects an appropriate return in the form of either a new revenue stream or an increase in profits of existing revenue streams - or both (Kim, Min, \& Chaiy, 2015). Returns from investments in new product development (NPD) are achieved by either selling the new offering to customers, i.e., by convincing customers of the new offering's value-creation potential, or by licensing out the technology (e.g., Bianchi, Frattini, Lejarra, \& Di Mini, 2014). This part of the new product development process is generally referred to as commercialization (Godin, 2006). Commercialization, in other words, forms a key interaction between research, technology, and innovation. There is a clear stream of discourse stretching from Schumpeter (1942) to Crossan and Apaydin (2010) suggesting that the innovation process is incomplete without commercialization (Adams, Bessant, \& Phelps, 2006). Despite the seemingly widespread acceptance of this terminology, an in-depth analysis of the use and definition of the term "commercialization" reveals significant ambiguity. This lack of a clear conceptualization hinders the development of theory, as a theory requires delimitations and definitions to satisfy the criteria of scientific discovery, which include refutation and falsification (Popper, 1963). This significant shortcoming is problematic not only for our understanding of commercialization but also for related fields of study. For example, Ernst and Fischer (2014) point out that research related to commercialization could improve our understanding of patenting strategies. In short, a clear commercialization construct is important for a clear understanding of innovation and research outcomes, especially for firms and research institutions like universities. 
At the same time, practitioners are highly interested in insights about various aspects of commercialization policy, including sales and marketing. An understanding of commercialization can advance our understanding of why some organizations repeatedly succeed in archiving rents from innovations while others do not. However, to gain such insight, we must move beyond merely looking at the personal attributes of sales personnel (Martin, 2011) and understand commercialization as an organizational phenomena.

This paper makes three significant contributions. First, we review the extant literature documenting the development and state of the commercialization construct. We map the dimensions used for defining commercialization within our sampled body of literature to assess the extent to which a shared understanding is evident in the extant research. Our analysis reveals that no shared definition of commercialization exists in management research. Thus, our second contribution is a proposed definition of "commercialization," which aims to establish common ground for the development of commercialization theory in the new product development field and possibly beyond. Third, we suggest essential avenues for future research with the aim of enhancing our understanding of commercialization, its dimensions, its antecedents, and its consequences.

These contributions are relevant for three reasons. First, this paper addresses an acknowledged gap in the extant commercialization research. Despite the call for academic contributions (de Jong et al., 2014) and practitioner interest in additional insights, this area remains underdeveloped. Second, in many paradigmatic debates surrounding innovation, commercialization plays a central role. A clear definition is needed to improve the quality of these discussions. For example, the theoretical debate regarding first-mover advantage versus fast-second advantages (Markides \& Geroski, 2004) essentially focuses on the capabilities that 
turn innovators (i.e., market actors realizing technically new offerings) into profiteers (i.e., market actors realizing a profit). A general assumption underlying this discussion is that observable systematic differences among market actors' commercial capabilities can explain performance differences. A clearly defined commercialization construct is needed to capture such differences. Third, any field of research that has not developed a shared and accepted set of concepts as well as a common understanding is in danger of conceptual ambiguity. Such conceptual ambiguity hinders scientific investigation, theory development, and testing in a Popperian sense (Popper, 1963), and risks confounding innovation policy and strategy recommendations with clusters of errors. In this respect, this paper lays the foundation for investigations into an important construct in new product development.

This paper is structured as follows. In the next section, we describe our methodology for identifying and selecting relevant publications for the literature review. We then outline the development of commercialization research through a descriptive analysis. For this purpose, we review research on or relating to commercialization published in five leading management journals over a period of three decades. We subsequently present the seven focal areas utilized by the authors in the 144 identified applications of the term "commercialization." Based on that analysis, we develop a theoretically grounded definition of commercialization. In the final section, we outline a research agenda for commercialization.

\section{METHODOLOGY}

Our aim with our methodology was threefold; 1) investigate if commercialization research exists, 2) investigating the extent of a shared understanding of the commercialization concept, 3) 
Finally, if the construct were ambiguous to suggest a way forward that both build on and advanced the current body of literature.

To reach the first aim we had to design a sample that was large enough to be representative, but also realistic to read in its entirety (Page \& Schirr, 2008). We decided to focus exclusively on journals in the review, as they ideally represent the latest, fastest, and (due to peer-review) most accepted research. To make such a sample we decide to limit our search to first innovation, which meant including the leading innovation journal Research Policy (RP) (Thongpapanl, 2012). The second most important innovation journal is the Journal of Product Innovation Management (JPIM) (ibid). That journal has a large focus on NPD which is also our more direct focus, although the literature review does encompass other topics relating to or making use of the commercialization construct. We could have chosen to add other journals within innovation studies, such as the Journal of business venturing, technovation, Journal of technology transfer. Relevant work in these journals is however likely cited in the journals we have included. As papers need time to gather a readership and citation we decided to limit the search to the first 30 years of the youngest, JPIM, of the two main journals. Next, we chose to expand the search in related fields. This was done to address the risk of inwardness typical of single-topic reviews (Denyer \& Tranfield, 2009). In line with the approach adopted by Page and Schirr (2008), we identified four management fields in which to extend our search into commercialization while keeping our focus on new product development: strategic management, entrepreneurship, marketing, and servitization. The selected journals were the Strategic Management Journal, the Journal of Operations Management, the Strategic Entrepreneurship Journal, and Marketing Science. These journals' current and five-year impact factors form a continuum around RP and JPIM ensuring broadness in our approach. 
As stated, we included papers published over a period of 30 years, i.e. from 1984 to 2014 . We searched all issues of the focal journals up to and including the publication year 2014 for the term “commercialization" via Wiley Online and Science Direct. Searches using deviations of the term, such as "commercializing," did not reveal additional material of relevance. ${ }^{1}$ The purpose of this literature review is to pinpoint a specific theoretical concept, namely commercialization. We identified 1.508 publications of interest.

Our initial screening of the material indicated that the identified publications included editorials, book reviews, and abstracts. As our focus is on original research, these publications were removed from our sample. Similarly, we eliminated papers in which commercialization was only mentioned in passing (i.e., without a definition or discussion of the term). For example, Teotia and Raju (1986) explicitly refer to commercialization in justifying the relevance of forecasting (the topic of their article), but their work makes no explicit contribution to the study of commercialization. The remaining 313 publications were registered in a database with their bibliometric details (e.g., publication year, authors) and descriptive dimensions, such as industry focus, employed methodology, and research design. ${ }^{2}$ All of these 313 publications were reviewed in their entirety. Table 1 provides the sample distribution per journal.

\footnotetext{
${ }^{1}$ A potential criticism of our focus on the term "commercialization" and close alternatives is that we may fail to take work dealing with specific aspects of commercialization, e.g., "product launch," into account. We justify our choice by our interest in the construct of "commercialization." We include some additional publications on specific aspects of commercialization when we discuss the different streams of commercialization research later in the paper.

${ }^{2}$ We use the categorization provided by Guo (2008: 28), as this categorization has previously been applied in JPIM: "Conceptual qualitative is exemplified by the literature reviews and arguments to develop new perspectives and to build qualitatively explored theoretical framework. It does not completely involve firsthand data collection. Conceptual quantitative, just as its name implies, uses mathematical tools and secondary data to present cases and proofs or to develop new models. In contrast, empirical qualitative studies employ qualitative approaches to collect primary data. Empirical quantitative studies require data collection through surveys or experiments and quantitatively analyze the records."
} 
Insert Table 1 about here

To benchmark our results, we compared our sample's definitions of commercialization to a previously published review of abstracts from JPIM's first 22 years (Guo, 2008). The method applied in that review consisted of grouping the terms launch strategy, launch tactic, competition and external environmental influences, diffusion, adoption and consumer evaluation of product attributes, and general launch management as distinct dimensions of commercialization when they appeared in the abstracts of papers (in contrast to our method of using full papers). Inspired by Luchs, Swan, \& Creusen (2016), we included the five most-cited articles within each category and located publications referring to these articles using Scopus with a bracket-based search method. This search proved disappointing, as we only identified 11 papers, of which four were already included in our sample. This was far from Guo's estimate of 84 articles. Potentially, the categories of competition and external environmental influences, diffusion, and adoption and consumer evaluation of product attributes were too ambiguous to target publications relevant for our study using this method. Notably, the removal of the words "general" from "launch management" provided no additional publications.

\section{Development of commercialization research}

Figure 1 illustrates the historical development of research on commercialization in terms of frequency of commercialization publications in the sample, i.e. the number of publications applying the commercialization construct relative to the total number of publications in the 
analyzed period. Overall, $4.4 \%^{3}$ of publications relate to commercialization. Furthermore, the $\mathrm{r}^{2}$ value of the trend line is $\sim .60$, which indicates that interest in the construct has grown over time. This is particularly notable given that the total number of publications has also risen.

Commercialization's share of publications remains rather stable at $6 \%$ over the last ten years. We performed the same analysis for publications solely for our Innovation Journal subsample (RP + JPIM) to test for topic-specific differences. Overall, $6 \%$ of the research published in RP and JPIM contributes directly to our understanding of commercialization. The $\mathrm{r}^{2}$ value is significant at a slightly lower level (.45). We, therefore, conclude that commercialization is an established topic in management journals and that it is receiving substantial attention. Given the steady development of commercialization research, the later interest in commercialization is not a fad or fashion - as there is no cyclical movement and no imitation process (Abrahamson, 1991). As such recent developments in terms of increased interest, job positions as "chief commercial officer" and a general tendency to use the term more often is not just another management fashion (Benders \& Van Veen, 2001; Kieser, 1997) but elements in a long-term development.

Insert Figure 1 about here

Methodologies and research designs employed in the publications in our sample are classified as "conceptual qualitative, conceptual quantitative, empirical qualitative and empirical quantitative" (Nakata \& Huang, 2005: 616). ${ }^{4}$ Each article was categorized as utilizing one of these four research designs as its dominant research method. However, owing to the wide range of adopted definitions of commercialization, the studies employ different measures. This makes

\footnotetext{
${ }^{3}$ This figure can further serve as a robustness test of the method in that removing RP from the sample only reduce the figure 0.1. This can be taken as a token for a representative sample.

${ }^{4}$ See footnote 2 for additional details.
} 
cross-comparison of the results problematic if not impossible. The majority of publications across all journals are empirical studies of commercialization that use either surveys or secondary data (cf. Figure 2). As indicated in Figure 2, commercialization has been studied from a variety of perspectives, which offer valid insights into different aspects of the phenomenon - constituting a research stream of commercialization in its own rights.

Insert Figure 2 about here

Table 2 provides additional bibliometric characteristics. Only 5\% of the articles in the sample are authored by practitioners. The typical commercialization scholar is involved in only one commercialization paper. We also note that the majority of commercialization research is carried out in North America. There is a small group of scholars involved in more than four of the papers included in our sample: Roger Calantone, Kenneth B. Kahn, Pablo D’Este Will Mitchell, Gerald J. Tellis, and Michael Song. The fact that $77 \%$ of the authors are involved in only one paper implies that the majority of contributors do not have commercialization as their main research area and that few, if any, of the researchers, have developed a research program on commercialization. Also, no one university seems to have aggregated thought leadership in this field. In other words, commercialization research exists but is a fragmented field of study.

Insert Table 2 about here 


\section{DEFINITION OF COMMERCIALIZATION}

In this section, we analyze the various definitions of commercialization found in our sample. We include both formal and explicit definitions of commercialization, as in Athaide, Meyers, \& Wilemon (1996), and implicit statements containing attributes of a (potentially) wider commercialization definition. We focus on the content of commercialization from a capabilitybased view of the firm, while we disregard definitions of antecedents and consequences of commercialization. Antecedents and consequences are not part of the definition itself but part of the nomological framework surrounding the construct. This process uncovered six distinct areas used for defining commercialization. These are each dealt with below. Numbers in parentheses show papers that contain the element.

- Product development (35): This perspective uses "commercialization" as an umbrella term for the entire process of new product development: "The commercialization phase starts after the design freeze. It involves the final product development modifications and the preparation and beginning of the production process and ends with the introduction to the marketplace" (Brettel, Heinemann, Engelen \& Neubauer, 2011: 253, based on Cooper, 1998). Similarly, "successful commercialization of a new product in biotechnology involves a lengthy and expensive product discovery and development phase, culminating in the final FDA approval" (De Carolis, Yang, Deeds, \& Nelling, 2009: 151). Likewise, ten papers highlight design as a part of commercialization.

- Launch preparation (24): In a more narrow application of the term, some definitions focus on the preparation of a product or service to be released to the market but do not include its actual release to consumers. An example can be found in Chiesa and 
Frattini (2011: 439): "Strategic decisions are taken prior to the launch of the innovation, and even before starting its development. They essentially define the context in which the launch of the new product occurs." In this view, commercialization typically involves the marketing department and is often related to strategy and tactical choices.

- Launch and initial marketing (38): In this interpretation, commercialization describes the process of releasing a product or service to the market. Chiesa and Frattini (2011: 439) refer to commercialization as "tactical decisions instead encompass the key elements of the marketing mix, and are thus concerned with the operational aspects of the innovation's launch." This process is often associated with issues related to implementation and early feedback from potential or early customers.

- Newness (31): In continuation of the launch focus, some definitions highlight newness as a defining element of commercialization, as in Coates and McDermott (2002: 442): “Our analysis suggests that the development of the emerging technology and the subsequent commercialization of that technology created a number of new competencies at Analog Devices." The focus on handling new products and services positions commercialization as a different theoretical construct than, for example, ongoing sales and marketing.

- Exploitation (89): This perspective, which is almost a direct opposite of the abovementioned interpretations of commercialization as newness, encompasses the distinct skills, activities, and capabilities that ensure ongoing delivery of a product or service. As such, commercialization is defined as all of the market-oriented processes that follow the new product's development. "Basic economic analysis suggests that any 
new investment in additional development or commercialization of a patented technology is justified only if the value of the discounted cash inflows from the investment is greater than the cost of the investment" (Levitas \& Chi, 2010: 218). Similarly, Bohlmann, Spanjil, Qualls and Rosa (2013: 237) note: “The firm's product strategy becomes manifest through product platform development and the commercialization of specific products." This view is aligned with the general interpretation of commercialization as expressed in the Oxford Dictionary5: "The process of managing or running something principally for financial gain.” This is also by far the most represented in the sample. However a large part of this is coming from papers dealing with university tech transfer and related topics, which was an ongoing and large debate in RP in our sample period.

- Complementary assets (33): Originally proposed by Teece (1986), this interpretation sees commercialization as an overall firm process involving complementary assets. In particular, Teece (1986) emphasizes that firms need complementary assets, such as product development, production, and marketing, for successful commercialization. Of the papers in the sample, 27 directly refer to complementary assets as a defining element of commercialization. An example is found in Chatterji and Fabrizio (2014: 1431): "firms develop complementary assets to support commercialization."

As the above list illustrates, the term "commercialization" has been attributed substantially different meanings spanning from single steps (e.g., a launch) to an entire process involving a multitude of steps (e.g., as a synonym for new product development), and it may be viewed as

\footnotetext{
${ }^{5}$ http://www.oxforddictionaries.com/. Last accessed Mar 27, 2016 at 21.46 CET
} 
including only new offerings or the entire product lifecycle management. Commercialization is implicitly or explicitly defined in 144 of the 313 publications in our sample. Each element in each definition was coded. This allowed us to test how the construct is used and whether usage is consistent or ambiguous. We propose two tests of this, a market-orientated test and a DNA test.

\section{Market-oriented test}

Journal research is in competition with each other for attention. While no direct currency exists, a proxy currency of scientific value can be argued to be citations. It is not without pitfalls to use this approach, as citations are given to both papers that are agreeable and disagreeable to the authors citing a paper, but at the very least many citations of a paper is some recognition of the underlying research. This part makes sense as the mean citation number is 530 for our sample. Another issue with using this method for our purpose is that citations might not relate to commercialization per say. That said, we did a simple OLS regression with citations being the dependent variable, and the independent variable was the above elements. As can be seen from Table 3 the results are inconclusive and explain a disappointingly small part of the citation number. Adding control valuables such as journal type and research type did not improve the result much. We, therefore, conclude that there is no market chosen commercialization definition.

Insert Table 3 about here

\section{DNA test}

To test if we could trace a commercialization definitive construct DNA, we constructed a Venn diagram illustrating the different definitions found in our sample (cf. Table 3). Venn diagrams are used, for example, in pharmacological research to establish and visualize patterns 
(Martin, Chadwick, Yi, Park, Lu, Ni, Gadkaree, Farhang, Becker, \& Maudsley, 2012). They are constructed of multiple intersecting regions that serve to showcase logical relationships and cooccurrences among different sets of data points, thereby sorting a construct in this case to its pure "DNA."

The results of this analysis (see Table 4) illustrate that no shared or dominant definition of commercialization exists. The highest occurrence - the combination of "adaptation and exploitation" and "newness and exploitation" and "product development and exploitation"—is only shared by $5.7 \%, 4.3 \%$, and $3.6 \%$ respectively of the sampled publications. The Venn diagram also indicates that neither do different schools of thought exist. The most surprising finding is that launch is not part of the most seen DNA types, which is likely surprising to many. In other words, we find a significant number of competing interpretations of the term. The term is used very differently by various authors, which highlights the rather fragmented interpretation of the concept. As "commercialization" is frequently used in many publications without a precise discussion of its meaning, there is a strong need to develop a clear definition. Given such differences, conceptual ambiguity for commercialization is high, and research results are not comparable. The lack of a proper definition creates a risk of conceptual ambiguity, which can cause confusion, and make comparison and comprehension unnecessarily challenging (Popper, 1962). ${ }^{6}$

Insert Table 4 about here

\footnotetext{
${ }^{6}$ For an illustrative analysis of causal ambiguity, see Elgie (1998).
} 
Despite the diversity in the use of the term, all of the definitions discussed above regard commercialization as a process (i.e., a set of activities) - and commercialization should, therefore, be viewed as an organizational capability. From a capability perspective, commercialization does not necessarily need to be successful. Success, performance, and market reactions are all outcomes that are influenced by a firm's capability to commercialize (as well as by other antecedents).

Based on the above, we define commercialization as the capability of a market actor to gain other market actors' acceptance of its value propositions. In the following, we explain the various elements of this proposed definition, and why they fit with and support the sample of reviewed research.

\section{Capability}

In recent years, management science has adopted the term "capability" when describing firms (for an overview of the capability-based view of the firm see, e.g., Sanchez, 2004). A capability is "a set of skills and proficiencies needed to achieve a goal" (Sabnis, Chatterjee, Grewal \& Lilien, 2013: 56; see also Day, 1994; Drucker, 1985; Li \& Calantone, 1998). In line with Teece, Pisano, and Shuen (1997), Winter (2003: 991) defines an organizational capability as “a high-level routine (or collection of routines)." In this regard, organizational capabilities are encapsulated in a firm's processes and systems. This enables firms to repeat activities over time and, thus, to sustain their capabilities. Moreover, certain elements of the processes and systems might be tacit and, therefore, hard for competitors to copy.

With regard to commercialization, our definition focuses on those routines and processes that connect the firm with those actors which are affected by the firm's value proposition. This focus mirrors recent calls for a stronger demand-side focus in strategic management (Priem, Li, 
\& Carr, 2012) and a better understanding of the micro-foundations of strategy (Barney \& Felin, 2013; Felin, Foss, Heimeriks \& Madsen, 2012; Foss \& Pedersen, 2016). In other words, we focus on the process and the resources in involved in performing that process.

\section{Market actor}

The underlying idea of commercialization is to convince a market actor to accept the firm's value proposition. We deliberately focus on market actors (as opposed to non-market actors) to exclude internal transactions and collaboration. A market actor has sovereignty (Hutt, 1936). In other words, all actors in a market choose the best available options according to their needs. Sovereignty applies to market actors because they are free to choose to engage in a transaction, as opposed to an internal unit, which may be limited in its choices owing to organizational restrictions. As market actors have the opportunity to choose, firms must be able to convince customers of the value of their offering. The work of Leenders, van Engelen \& Kratzer (2007) and Candi (2010) on the role of design and aesthetics as a way to convince customers provides practical illustrations of the impact of customer sovereignty from an innovation perspective.

We use the term "market actor" rather than "customer" because the latter term might limit the identification of the relevant set of actors that a firm needs to convince. Firms are embedded in ecosystems and networks in which many different market actors can influence their development. Not all of these market actors are customers in a traditional sense. For example, when aircraft producers like Airbus and Boing commercialize super-large aircraft, they need to convince airports, airlines, passengers, and authorities (to name only the most prevalent actors). All of these market actors can have a decisive impact on a product's success, but some of them are not customers. Therewith, we apply a stakeholder view towards the downstream market. 


\section{Value proposition}

Suppliers offer a value proposition to downstream market actors. As noted by Hammer (1996: 12), a process perspective on the firm "requires that we start with customers and what they want from us, and work backward from there." A value proposition describes the inputs that a supplier delivers to the customer and the resources the customer offers in return to enable the supplier to create value (for discussions of value propositions, see Ballantyne, Frow, Varey \& Payne, 2011; Storbacka and Nenonen, 2011; Wouters, Anderson, Narus, \& Wynstra, 2009). We utilize the term "value proposition," as it encompasses products and services. Moreover, the term is not industry-specific: all firms offer value propositions, but many industries have specific terms for their offerings. As we wish to establish a general definition, we opt for a general yet distinct and established term.

\section{Acceptance}

For a firm, the acceptance of its value proposition is key. If market actors do not accept the value proposition, then the supplier has no revenue stream and will eventually face bankruptcy. Acceptance is created throughout a cognitive process, which is commonly described as the Attention-Interest-Desire-Action (AIDA) process (Copeland, 1925). The AIDA perspective posits that the decision process moves from initial awareness to gaining interest and building up the desire to finally accepting the supplier's value proposition. This logic is generally applicable to buying processes, and it also applies to radical innovations: "In order to successfully develop and commercialize disruptive innovations, not only does the firm need to conceptualize and develop the innovation in the first place; it must also be successful in reaching more than just a niche market of innovators-early adopters" (Slater \& Mohr, 2006: 31). Similar stage-based approaches to acceptance are found throughout the innovation literature (e.g., Rogers, 2010). 
Our suggested definition is broader than established views on sales and marketing. The sales process is defined as "any of a number of activities designed to promote customer purchase of a product or service. The process generally includes stages such as assessing customer needs, presenting product features and benefits to address those needs and negotiation on price, delivery and other elements" (AMA, 2006). While this definition is closely related to our definition of commercialization, its application is operational and focuses on existing offerings and negotiations with individual customers. In practice, sales departments are often responsible for specific customer relationships. Marketing is broadly defined as " a set of processes for creating, communicating, and delivering value to customers and for managing customer relationships in ways that benefit the organization and its stakeholders" (AMA, 2006). This definition also includes creating and delivering value and, as such, reaches much further than our definition. In practice, however, marketing departments often deal with mass communication and the generation of new customer leads. In other words, they handle much less than the definition claims.

In our understanding, commercialization is more focused on market actors and includes both new and existing offerings. If we apply an adapted version of Ansoff's (1957) growth matrix, we find that commercialization covers all four areas (cf. Figure 3), while sales, marketing, launch, and business development address specific areas.

Insert Figure 3 about here 


\section{AN EMERGING AGENDA FOR COMMERCIALIZATION RESEARCH}

While we have documented the significant research interest in commercialization, our analysis has also revealed various opportunities to develop a better understanding of commercialization. The use of different interpretations and definitions of the term may have hindered the development of the field. We, therefore, suggest a definition to create a foundation for future research that can advance our understanding of this vital capability. A common definition allows researchers to adhere to a deductive approach regarding, for example, questioning and subsequent scientific expansion (Camerer, 1985).

In this section, we suggest some avenues for further research on commercialization that together serve as a research agenda for commercialization. Our suggestions focus on five areas: 1) further conceptualization of commercialization; 2) further development of theory concerning commercialization processes; 3) the development of instruments for empirical measurement, 4) theoretical perspectives, and 5) the consequences of commercialization capability for a firm's performance.

\section{Further conceptualization of commercialization}

Our definition highlights the fundamental aim of commercialization: convincing a market actor to accept a supplier's value proposition. Moreover, it emphasizes the importance of market actors voluntarism to accept another actors value proposition due to sovereignty. This emphasis opens up for some reflections regarding voluntarism among market actors and variations in markets.

Voluntarism among market actors is key for understanding commercialization. Technology introduces risks and uncertainties into new product development, and customer sovereignty does 
the same for commercialization. In other words, customer sovereignty affects the extent to which market-actor acceptance is predictable. This aspect warrants further attention, especially regarding the measurement of success and the prediction of outcomes. It also raises issues regarding the usefulness of the commercialization concept in monopoly situations. For example, to what extent do monopolists need commercialization capabilities when acceptance can be enforced rather than earned? What is the impact on success in this situation?

As commercialization is interlinked with research and development, it can be (partially) understood as (new) customer development (NCD) in parallel with (new) product development (NPD). Given such a conceptual relation, it is surprising that little transfer of concepts has taken place between the two domains. Additional research may conceptualize and test the extent to which NPD insights apply to NCD (e.g., in relation to stage-gate models, portfolio planning, and risk management).

In addition, variations in markets may be related to variations in commercialization capability. For instance, markets with only one customer, such as a government, or markets in which products and services are highly regulated may require different variants of commercialization. According to Pinkse, Bohnsack, and Kolk (2014), external incentives, such as governmental schemes, can shape or even create a market, which in turn influences commercialization efforts and methods. Likewise, commercialization in highly competitive markets or markets with rates of change may differ. The pharmaceutical industry, for example, is characterized by a tendency to assume that commercialization will occur after the authorities approve the product as long as the company can produce and distribute sufficient volumes (Blau, Pekny, Varma, \& Bunch, 2004). 
Another important issue about commercialization is the value proposition itself. Is the value proposition a product or a service that has been developed by the firm? Alternatively, is it the technological resources resulting from the development of a new product or service (e.g., patents and know-how)? Given ongoing diffusion of innovation in the open-innovation paradigm (Chesbrough, 2003), the concept of commercialization may be more co-occurring with rather than follow development. It may increasingly lead to the commercialization of new technologies that are disembodied from physical artifacts or service processes (Bianchi, Frattini, Lejarraga, \& Di Minin, 2014). The appropriation of value from these predominantly tacit and highly complex knowledge assets through licensing transactions may require different commercialization capabilities than those needed for selling goods and services. This shift in focus may also increase the risk profile, as the diffusion of knowledge assets may benefit competitors and undermine the firm's competitive advantage (Teece, 1986; Arora, Fosfuri, \& Gambardella, 2001).

\section{Processes}

Commercialization should be considered as a set of linked and interdependent activities that build a capability. Future research should disentangle the nature of this process regarding how it is embedded in the functions and internal organization of the firm on the one hand, and how it relates to individual decision makers on the other hand. One way to approach this task is to separate commercialization as an organizational process from commercialization as a managerial process, where the latter focuses on individual decision makers and their relationships rather than on the organization as a whole. Along these lines, Garvin (1998) suggests an integrated framework for understanding organizational and managerial processes, which can serve as a useful basis for developing a process-oriented definition of commercialization. 
Given the importance of commercialization for the existence of a firm, it is important to understand its antecedents. For example, 24 of the papers included in this study identify internal cooperation in a firm as a significant antecedent of commercialization. In other words, activities that revolve around cross-department cooperation are viewed as prerequisites for the successful commercialization of products or services in the market: "Less-divisionalized firms would be expected to pursue R\&D in a broader range of areas, since looking ahead they can expect better chances of successful commercialization due to better interdivisional coordination. Conversely, firms with greater divisionalization will diversify R\&D more narrowly since their capacity for downstream coordination is less" (Argyres, 1996: 401). In this perspective, commercialization and $R \& D$ processes are often intertwined throughout the NPD process. These interactions may continue throughout the entire life cycle of an offering.

\section{Measurement}

We have argued that commercialization is best understood as a particular set of linked and interdependent activities pertaining to individuals and to the organization as a whole. Although we have suggested a definition of commercialization, instruments for measuring commercialization need to be developed for both quantitative and qualitative studies. Notably, processes provide a convenient level of analysis with beginnings and ends, and with boundaries that can be defined with some precision and minimum overlap (Garvin, 1998). For quantitative settings, we need to develop scales and measures that capture the degree of a firm's commercialization capability. While R\&D, productivity, and profitability are among the standard items in various official databases, indices for commercialization are not. Recently, Mishra and Modi (2016) estimated marketing capability as the inefficiency score of a production function. This is a somewhat unusual way to capture commercialization. We, therefore, need to develop 
tools suitable for capturing data for studying commercialization. In addition to censor data, empirical studies need to analyze different self-reporting scales in order to develop suitable instruments. For qualitative settings, we require an understanding of how to identify and describe a firm's commercialization capability regarding which questions to ask, which artifacts to look for, and which behaviors to notice.

\section{Theoretical perspectives}

In our definition, we focus on commercialization as a process, and we suggest that capability-based theories of the firm provide the proper theoretical foundation for commercialization research. However, we also wish to highlight some key complementarities between capability-based theories and transaction-cost economics, as already discussed by Alchian and Demsetz (1972) and Langlois and Foss (1997), among others. Capability and governance issues are closely interrelated. For example, the issue of access to complementary assets significantly affects governance challenges, as firms may choose to build capabilities up by themselves, cooperate with other companies, or license a relevant technology (Teece, 1986).

Transaction-cost economics have been explicitly applied in the study of commercialization (e.g., Stumpa, Atahide, \& Joshi, 2002). When the boundary of a firm is given by the marginal return of one more transaction within the firm exceeding the cost of a market transaction (Coase, 1937; Williamson, 1975, 1979), the role of commercialization is affected by transaction-cost considerations. Song and Thieme (2009) apply transaction-cost economics to argue that a product's transition from the predesign stage to commercialization lowers the level of uncertainty, meaning that the boundaries of the firm become clearer.

On a related note, 19 of the publications in our review emphasize various aspects of uncertainty and costs in relation to commercialization. The majority of these papers argue that 
uncertainties, risks, and costs increase as a new product development project moves closer to commercialization. For example, Chiesa and Frattini (2011) argue that commercialization is a critical stage of the technological-innovation process, mainly because of the high risks and costs it entails. They show that commercialization is particularly challenging in volatile, fast-moving, and uncertain high-tech markets where the window of opportunity is extremely narrow. Others argue that although costs increase, uncertainty is reduced as a new product moves closer to the commercialization stage (Knott, 2003). While these disagreements open up for important research in their own right, we believe that uncertainties, risks, and costs are not defining focal areas of commercialization. Instead, we view them as attributes of any organizational and managerial process. Future studies may analyze the extent to which commercialization entails greater risks, uncertainties, and costs than other organizational capabilities and under what circumstances. They might also analyze how firms can overcome the higher risks and costs associated with commercialization.

\section{Performance outcomes}

After the development of suitable measures, the impact of commercialization on firm performance can be investigated. There is a general notion that "good commercialization capability leads to good performance." However, the extent of this impact remains unknown, as do the conditions for greater or lesser impacts (moderating factors). All of these issues constitute interesting fields for future research. Some work has been carried out in relation to commercialization's impact on performance. For instance, Udell, Bottin, and Glass (1993) frame commercialization as a choice between new venture creation and licensing. This view is nuanced in Boyd and Spekman (2010: 602), who state that "licensors that emphasize value creation may wish to follow a less restrictive commercialization of their products so as to generate funds faster 
for future R\&D activity. Alternatively, a firm emphasizing value appropriation may wish to follow a more restrictive distribution strategy to enter the market itself at a later date." Bianchi et al. (2014) add that because fewer sales people are needed to support licensing opportunities than in direct sales, commercialization via licensing is more cost effective for innovators. Thus far, whether licensing offers better returns as well is unclear. Much unexplored territory remains with regard to the impact of commercialization.

A significant number of the publications in our study address licenses. We, therefore, suggest a separate literature review focused on this subsample that investigates the implications of licensing for commercialization strategies and tactics. Based on the commercialization definition offered in this paper, such research could help answer fundamental questions regarding how the creation of capability sets in firms can improve financial performance in correlation with licensing decisions.

\section{CONCLUSION}

"Commercialization" is a common term in NPD research, and its definition is widely assumed to be known. We have shown that while the term is used widely and deeply enough for it to be called scientific, it suffers from a large degree of conceptual ambiguity. The current conceptually, and therefore causal, ambiguity is not only unsatisfactory, but it also hinders the further development of commercialization research. To overcome this situation, we suggest a definition of commercialization that builds upon theoretically well-established elements, such as capability, acceptance, market actor, and value proposition. The proposed definition will allow us to better delimit the field of study and to achieve a common understanding, which we hope will serve as the foundation for additional research. A shared and comparable definition of 
commercialization is of significant importance in evaluating innovation research, but also for policy suggestions and effects.

\section{References}

Abrahamson, Eric. 1991. Managerial fads and fashions: The diffusion and rejection of innovations. Academy of Management Review, 16 (3): 586-612.

Adams, R., J. Bessant, and R. Phelps. 2006. Innovation management measurement: A review. International Journal of Management Reviews, 8 (1): 21-47.

Alchian, A.A. and Demsetz, H., 1972. Production, information costs, and economic organization. The American Economic Review, 62(5): 777-795.

AMA. 2006. Dictionary of marketing terms. www.marketingpower.com, January, 2006.

Ansoff, I. 1957. Strategies for Diversification. Harvard Business Review, 35 (5): 113-124.

Argyres, N. 1996. Capabilities, technological diversification and divisionalization. Strategic Management Journal, 17 (5): 395-410.

Arora, A., A. Fosfuri, and A. Gambardella. 2001. Markets for Technology: The Economics of Innovation and Corporate Strategy. Cambridge, MA: MIT Press.

Athaide, G. A., P. W. Meyers, and D. L. Wilemon. 1996. Seller-buyer interactions during the commercialization of technological process innovations. Journal of Product Innovation Management, 13 (5): 406-421. 
Ballantyne, D., P. Frow, R. J. Varey, and A. Payne. 2011. Value propositions as communication practice: Taking a wider view. Industrial Marketing Management, 40 (2): 202-210.

Barney, J., and T. Felin. 2013. What are microfoundations?. The Academy of Management Perspectives, 27 (2): 138-155.

Benders, Jos, and Kees Van Veen. 2001. What's in a fashion? Interpretative viability and management fashions. Organization, 8 (1): 33-53.

Bianchi, M., F. Frattini, J. Lejarraga, and A. Di Minin. 2014. Technology exploitation paths: combining technological and complementary resources in new product development and licensing. Journal of Product Innovation Management, 31 (S1): 146-169.

Blau, G. E., J. F. Pekny, V. A. Varma, and P. R. Bunch. 2004. Managing a Portfolio of Interdependent New Product Candidates in the Pharmaceutical Industry. Journal of Product Innovation Management, 21 (4): 227-245.

Bohlmann, J. D., J. Spanjol, W. J. Qualls, and J. A. Rosa. 2013. The interplay of customer and product innovation dynamics: an exploratory study. Journal of Product Innovation Management, 30 (2): 228-244.

Boyd, D. E., and R. E. Spekman. 2010. The Licensing of Market Development Rights within Technology Alliances: A Shareholder Value Perspective. Journal of Product Innovation Management, 27 (4): 593-605.

Brettel, M., F. Heinemann, A. Engelen, and S. Neubauer. 2011. Cross-functional integration of $\mathrm{R} \& \mathrm{D}$, marketing, and manufacturing in radical and incremental product innovations and its 
effects on project effectiveness and efficiency. Journal of Product Innovation Management, 28 (2): 251-269.

Camerer, C., 1985. Redirecting research in business policy and strategy. Strategic Management Journal, 6 (1): 1-15.

Candi, M. 2010. Benefits of Aesthetic Design as an Element of New Service Development. Journal of Product Innovation Management, 27 (7): 1047-1064.

Chatterji, A. K., and K. R. Fabrizio. 2014. Using users: When does external knowledge enhance corporate product innovation?. Strategic Management Journal, 35 (10): 1427-144.

Chesbrough, H. 2003. Open Innovation: The New Imperative for Creating and Profiting from Technology. Boston, USA: Harvard Business School Press.

Chiesa, V., and F. Frattini. 2011. Commercializing Technological Innovation: Learning from Failures in High-Tech Markets. Journal of Product Innovation Management, 28 (4): 437454.

Coase, R. H. 1937. The Nature of the Firm. Economica, 4 (16): 386-405.

Coates, T. T., and C. M. McDermott. 2002. An exploratory analysis of new competencies: a resource based view perspective. Journal of Operations Management, 20 (5): 435-450.

Copeland, M. T. 1925. Principles of Merchandising. New York: Shaw.

Cooper, R. G. 1998. Product leadership: Creating and launching superior new products. Cambridge, MA: Perseus Books. 
Crossan, M. M., and M. Apaydin. 2010. A multi-dimensional framework of organizational innovation: A systematic review of the literature. Journal of Management Studies, 47 (6): 1154-1191.

Day, G. S. 1994. The capabilities of the market-driven organizations. Journal of Marketing, 58 (4): $37-52$.

De Carolis, D. M., Y. Yang, D. L. Deeds, and E. Nelling. 2009. Weathering the storm: the benefit of resources to high-technology ventures navigating adverse events. Strategic Entrepreneurship Journal, 3 (2): 147-160.

Denyer, D., and D. Tranfield. 2009. Producing a systematic review. In Buchanan, D., and A. Bryman (Eds.), The SAGE handbook of organizational research methods. Sage Publications Ltd.

Drucker, P. F. 1985. The discipline of innovation. Harvard Business Review, 63 (3): 67-72.

Elgie, R. 1998. The classification of democratic regime types: Conceptual ambiguity and contestable assumptions. European Journal of Political Research, 33 (2): 219-238.

Ernst, H. and M. Fischer. 2014. Integrating the R\&D and Patent Functions: Implications for New Product Performance. Journal of Product Innovation Management, 31 (S1): 118-132.

Felin, T., N. J. Foss, K. H. Heimeriks, and T. L. Madsen. 2012. Microfoundations of routines and capabilities: Individuals, processes, and structure. Journal of Management Studies, 49 (8): $1351-1374$. 
Foss, N. J., and T. Pedersen. 2016. Microfoundations in Strategy Research. Strategic Management Journal, 37 (13): E22-E34.

Garvin, D. A. 1998. The Processes of Organization and Management. Sloan Management Review, 39(4): 33-50.

Godin, B. 2006. The Linear Model of Innovation. Science, Technology, and Human Values, 31 (6): 639-667.

Guo, L. 2008. An Analysis of 22 Years of Research in JPIM. Journal of Product Innovation Management, 25 (3): 249-260.

Hammer, M. 1996. Beyond Reengineering: How the eprocess-centered organization is changing our work and lives. New York: Harper Business.

Heidegger, M. 1962. Being and Time. 1927. Trans. John Macquarrie and Edward Robinson. New York: Harper.

Hutt, W. H. 1936. Economists and the public: a study of competition and opinion. Transaction Publishers.

Kieser, A. 1997. Rhetoric and myth in management fashion. Organization, 4: 49-74.

Kim, N., S. Min, and S. Chaiy. 2015. Why Do Firms Enter a New Product Market? A TwoDimensional Framework for Market Entry Motivation and Behavior. Journal of Product Innovation Management, 32 (2): 263-278. 
Knott, A. M. 2003. Persistent heterogeneity and sustainable innovation. Strategic Management Journal, 24 (8): 687-705.

Langlois, R. E., and N. J. Foss. 1997. Capabilities and governance. The rebirth of production in the theory of economic organization. KYKLOS, 52 (2): 201-218.

Leenders, R.T. a. J., J.M.L. van Engelen, and J. Kratzer. 2007. Systematic Design Methods and the Creative Performance of New Product Teams: Do They Contradict or Complement Each Other? Journal of Product Innovation Management, 24 (2): 166-179.

Levitas, E., and T. Chi. 2010. A look at the value creation effects of patenting and capital investment through a real options lens: the moderating role of uncertainty. Strategic Entrepreneurship Journal, 4 (3): 212-233.

Li, T., and R. J. Calantone. 1998. The impact of market knowledge competence on new product advantage: conceptualization and empirical examination. Journal of Marketing, 62 (4): 13-29.

Luchs, M. G., K. S. Swan, and M. E. H. Creusen. 2016. Perspective: A Review of Marketing Research on Product Design with Directions for Future Research. Journal of Product Innovation Management, 33 (3): 320-341.

Markides, C. C., and P. A. Geroski. 2004. Fast second: How smart companies bypass radical innovation to enter and dominate new markets. San Francisco: Jossey-Bass. 
Martin, B., W. Chadwick, T. Yi, S.-S. Park, D. Lu, B. Ni, S. Gadkaree, K. Farhang, K. G. Becker, and S. Maudsley. 2012. VENNTURE-a novel Venn diagram investigational tool for multiple pharmacological dataset analysis. PLoS One, 7 (5): 1-8.

Martin, S. W. 2011. Seven personality traits of top salespeople. HBR Blog Network 27.

Mishra, S. and B. S. Modi. 2016. Corporate social responsibility and shareholder wealth: the role of marketing capability. Journal of Marketing, 80: 26-46.

Nakata, C., \& Huang, Y. 2005. Progress and promise: the last decade of international marketing research. Journal of Business Research, 58 (5): 611-618.

Page, A. L., and G. R. Schirr. 2008. Growth and development of a body of knowledge: 16 years of new product development research, 1989-2004. Journal of Product Innovation Management, 25 (3): 233-248.

Pinkse, J., R. Bohnsack, and A. Kolk. 2014. The role of public and private protection in disruptive innovation: the automotive industry and the emergence of low-emission vehicles. Journal of Product Innovation Management, 31 (1): 43-60.

Popper, K. 1963: Conjectures and Refutations: The Growth of Scientific Knowledge. London.

Priem, R. L., S. Li, and J. C. Carr. 2012. Insights and new directions from demand-side approaches to technology innovation, entrepreneurship, and strategic management research. Journal of Management, 38 (1): 346-374.

Rogers, E.M., 2010. Diffusion of innovations. Simon and Schuster. 
Sabnis, G., S. C. Chatterjee, R. Grewal, and G. L. Lilien. 2013. The sales lead black hole: on sales reps' follow-up of marketing leads. Journal of Marketing, 77 (1): 52-67.

Sanchez, R. 2004. Understanding competence-based management: Identifying and managing five modes of competence. Journal of Business Research, 57 (5): 518-532.

Schumpeter, J. A. 1942. Socialism, capitalism and democracy. Harper and Brothers.

Slater, S.F., and J. J. Mohr. 2006. Successful development and commercialization of technological innovation: insights based on strategy type. Journal of Product Innovation Management, 23 (1): 26-33.

Song, M., and J. Thieme. 2009. The role of suppliers in market intelligence gathering for radical and incremental innovation. Journal of Product Innovation Management, 26 (1): 43-57.

Storbacka, K., and S. Nenonen. 2011. Scripting markets: From value propositions to market propositions. Industrial Marketing Management, 40 (2): 255-266.

Stumpa, R. L., G. A. Atahide, and A. W. Joshi. 2002. Managing seller-buyer new product development relationships for customized products: a contingency model based on transaction cost analysis and empirical test. Journal of Product Innovation Management, 19 (6): 439-454.

Teece, D. J. 1986. Profiting from technological innovation: implications for integration, collaboration, licensing and public policy. Research Policy, 15 (6): 285-305.

Teece, D. J., G. Pisano, and A. Shuen. 1997. Dynamic capabilities and strategic management. Strategic Management Journal, 18 (7): 509-533. 
Teotia, A. P. S., and P. S. Raju. 1986. Forecasting the market penetration of new technologies using a combination of economic cost and diffusion models. Journal of Product Innovation Management, 3 (4): 225-237.

Thongpapanl, N. 2012. The changing landscape of technology and innovation management: An updated ranking of journals in the field. Technovation, 32 (5): 257-271.

Udell, G. G., R. Bottin, and D. D. Glass. 1993. The Wal-Mart innovation network: An experiment in stimulating American innovation. Journal of Product Innovation Management, 10 (1): 23-34.

Williamson, O.E., 1975. Markets and hierarchies. New York.

Williamson, O.E., 1979. Transaction-cost economics: the governance of contractual relations. Journal of Law \& Economics, 22(2): 233-261.

Winter, S. G. 2003. Understanding dynamic capabilities. Strategic Management Journal, 24 (10): 991-995.

Wouters, M., J. C. Anderson, J. A. Narus and F. Wynstra. 2009. Improving sourcing decisions in NPD projects: Monetary quantification of points of difference. Journal of Operations Management, 27 (1): 64-77. 
Table 1: Overview of literature sample

\begin{tabular}{|c|c|c|c|c|c|c|}
\hline Journal & Area & $\begin{array}{l}\text { Search } \\
\text { on term }\end{array}$ & $\begin{array}{l}\text { Sorted } \\
\text { for } \\
\text { relevance }\end{array}$ & $\begin{array}{l}\text { Containing } \\
\text { definition }\end{array}$ & $\begin{array}{l}\text { Impact } \\
\text { factor } \\
1 / 5 \text { year }\end{array}$ & $\begin{array}{l}\text { Publication } \\
\text { Age }\end{array}$ \\
\hline Research Policy & Innovation & 850 & 99 & 44 & $4.495 / 6.265$ & 46 \\
\hline $\begin{array}{l}\text { Journal of } \\
\text { Operations } \\
\text { Management }\end{array}$ & $\begin{array}{l}\text { Operation } \\
\text { management } \\
\text { (servitization) }\end{array}$ & 21 & 9 & 5 & $5.207 / 8.618$ & 36 \\
\hline $\begin{array}{l}\text { Strategic } \\
\text { Entrepreneurship } \\
\text { Journal }\end{array}$ & Entrepreneurship & 48 & 20 & 8 & $2.537 / 3.485$ & 9 \\
\hline $\begin{array}{l}\text { Marketing } \\
\text { Science }\end{array}$ & $\begin{array}{l}\text { Sales \& } \\
\text { Marketing }\end{array}$ & 28 & 10 & 7 & $2.163 / 3.588$ & 34 \\
\hline $\begin{array}{l}\text { Strategic } \\
\text { Management } \\
\text { Journal }\end{array}$ & Strategy & 214 & 75 & 42 & $4.561 / 6.652$ & 36 \\
\hline $\begin{array}{l}\text { Journal of } \\
\text { Product } \\
\text { Innovation } \\
\text { Management }\end{array}$ & Innovation & 347 & 100 & 38 & $3.759 / 4.358$ & 33 \\
\hline TOTAL & & 1.508 & 313 & 144 & & \\
\hline
\end{tabular}


Table 2: Authorship characteristics

\begin{tabular}{|l|r|r|}
\hline Author Gender & \multicolumn{1}{|c|}{$\#$} & \multicolumn{1}{|c|}{$\%$} \\
\hline Male & 441 & $73 \%$ \\
\hline Female & 163 & $27 \%$ \\
\hline & & \\
\hline Author Background & & \\
\hline Academic & 571 & $95 \%$ \\
\hline Practioner & 33 & $5 \%$ \\
\hline & & \\
\hline Author Geography & & \\
\hline North America & 331 & $55 \%$ \\
\hline Europe & 228 & $38 \%$ \\
\hline Asia & 29 & $5 \%$ \\
\hline Rest of the World & 16 & $3 \%$ \\
\hline & & \\
\hline$\#$ of paper involvement & & \\
\hline 1 & 400 & $66 \%$ \\
\hline 2 & 55 & $18 \%$ \\
\hline 3 & 10 & $5 \%$ \\
\hline 4 & 7 & $5 \%$ \\
\hline 5 & 2 & $2 \%$ \\
\hline 6 & 2 & $2 \%$ \\
\hline 7 & 1 & $1 \%$ \\
\hline 8 & 1 & $1 \%$ \\
\hline
\end{tabular}




\section{Table 3: Regression results}

\begin{tabular}{|c|c|c|c|c|c|c|c|}
\hline \multirow{10}{*}{ Current } & \multirow{10}{*}{\multicolumn{2}{|c|}{$\begin{array}{c}\text { Response } \\
\text { Variable } \\
\text { Citations = }\end{array}$}} & & & \multirow[t]{2}{*}{$\begin{array}{l}\text { Explanatory } \\
\text { Variable }\end{array}$} & \multirow{2}{*}{$\begin{array}{c}\text { Standard } \\
\text { Error } \\
(432.0)\end{array}$} & \multirow{2}{*}{$\begin{array}{l}\text { P-Value } \\
\text { [0.054] }\end{array}$} \\
\hline & & & & & & & \\
\hline & & & 202.9 & $x$ & Product development & $(513.4)$ & [0.693] \\
\hline & & & 333.2 & $x$ & Newness & (511.1) & {$[0.516]$} \\
\hline & & & 274.7 & $x$ & Internal cooperation & (590.8) & [ 0.643$]$ \\
\hline & & & 773.5 & $x$ & Complementary assets & (507.3) & {$[0.130]$} \\
\hline & & & 18.97 & $x$ & Launch preparation & (693.9) & [ 0.978 ] \\
\hline & & & 104.7 & $x$ & Launch and initial marketing & (561.7) & {$[0.852]$} \\
\hline & & & 119.5 & $x$ & Adaptation & $(506.5)$ & {$[0.814]$} \\
\hline & & - & 437.4 & $x$ & Exploitation & $(438.2)$ & {$[0.320]$} \\
\hline
\end{tabular}

Table 4: Venn results

\begin{tabular}{|c|c|c|}
\hline Names & Total & Papers \\
\hline Adaptation Exploitation & 8 & $\begin{array}{l}\text { P85 P115 P50 P2 P14 P128 } \\
\text { P53 P125 }\end{array}$ \\
\hline Exploitation Newness & 6 & $\begin{array}{l}\text { P138 P113 P54 P112 P111 } \\
\text { P137 }\end{array}$ \\
\hline Exploitation Product development & 5 & P135 P133 P121 P105 P144 \\
\hline Exploitation Launch and initial marketing & 4 & P5 P75 P94 P72 \\
\hline $\begin{array}{l}\text { Exploitation Launch and initial marketing Launch preparation Product development internal } \\
\text { cooperation }\end{array}$ & 3 & P83 P84 P65 \\
\hline Exploitation Newness Product development & 3 & P134 P140 P129 \\
\hline Adaptation Complimentary assets Exploitation & 3 & P114 P104 P89 \\
\hline Exploitation internal cooperation & 3 & P143 P126 P107 \\
\hline Complimentary assets Exploitation & 3 & P131 P103 P116 \\
\hline $\begin{array}{l}\text { Adaptation Exploitation Launch and initial marketing Launch preparation Newness Product } \\
\text { development internal cooperation }\end{array}$ & 2 & P20 P10 \\
\hline Exploitation Launch and initial marketing Newness Product development & 2 & P30 P139 \\
\hline Exploitation Launch and initial marketing Launch preparation Product development & 2 & P92 P88 \\
\hline Launch and initial marketing Launch preparation internal cooperation & 2 & P36 P27 \\
\hline Exploitation Launch and initial marketing internal cooperation & 2 & P37 P19 \\
\hline Adaptation Product development & 2 & P15 P9 \\
\hline Launch and initial marketing Launch preparation & 2 & P96 P32 \\
\hline
\end{tabular}

\section{Notes:}


The table does not display single definitions based on only one element.

The table does not display all single paper results (unique combinations of elements in definition). 
Figure 1: Year of Publication
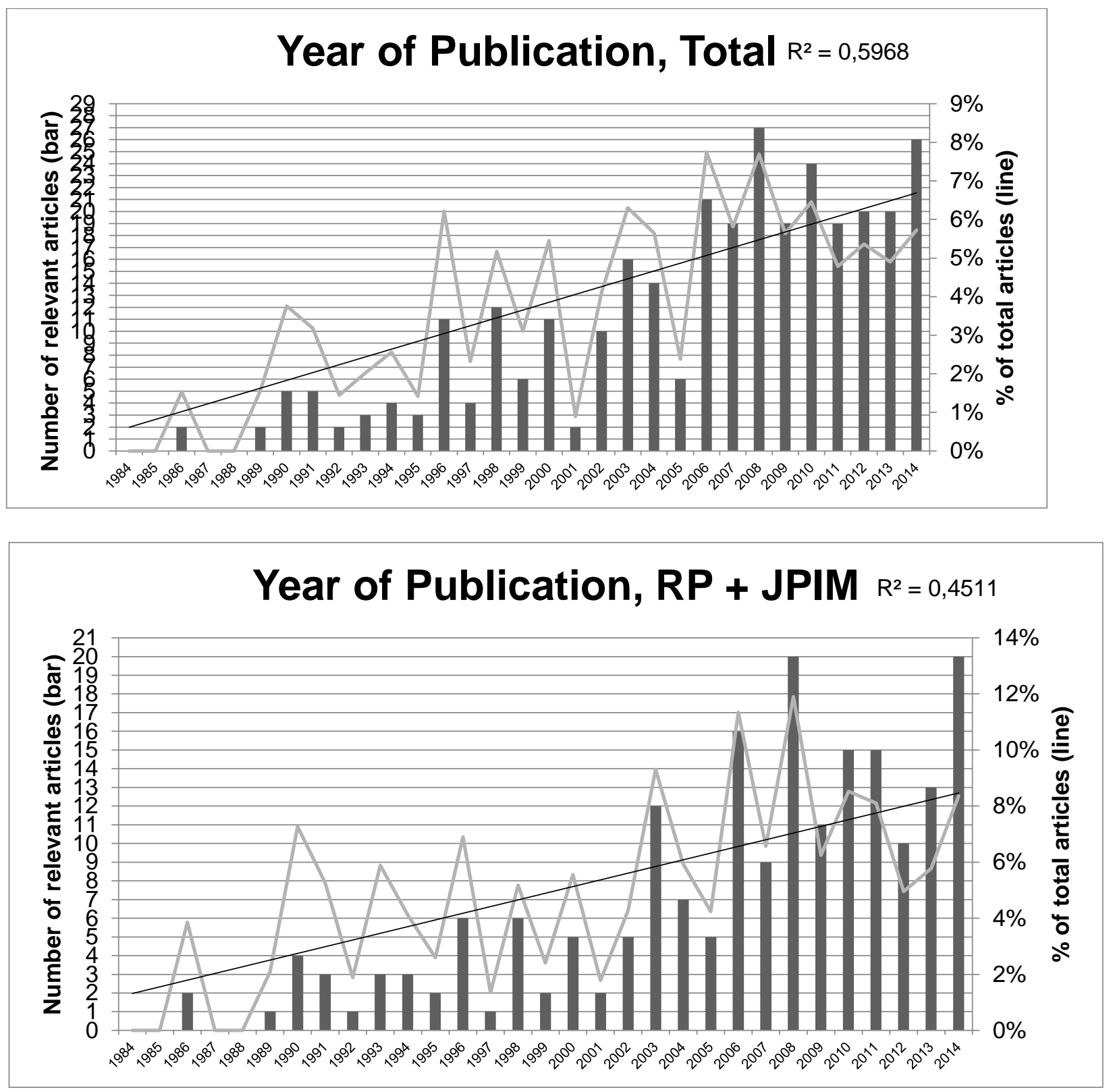


\section{Figure 2: Method and Research Type}
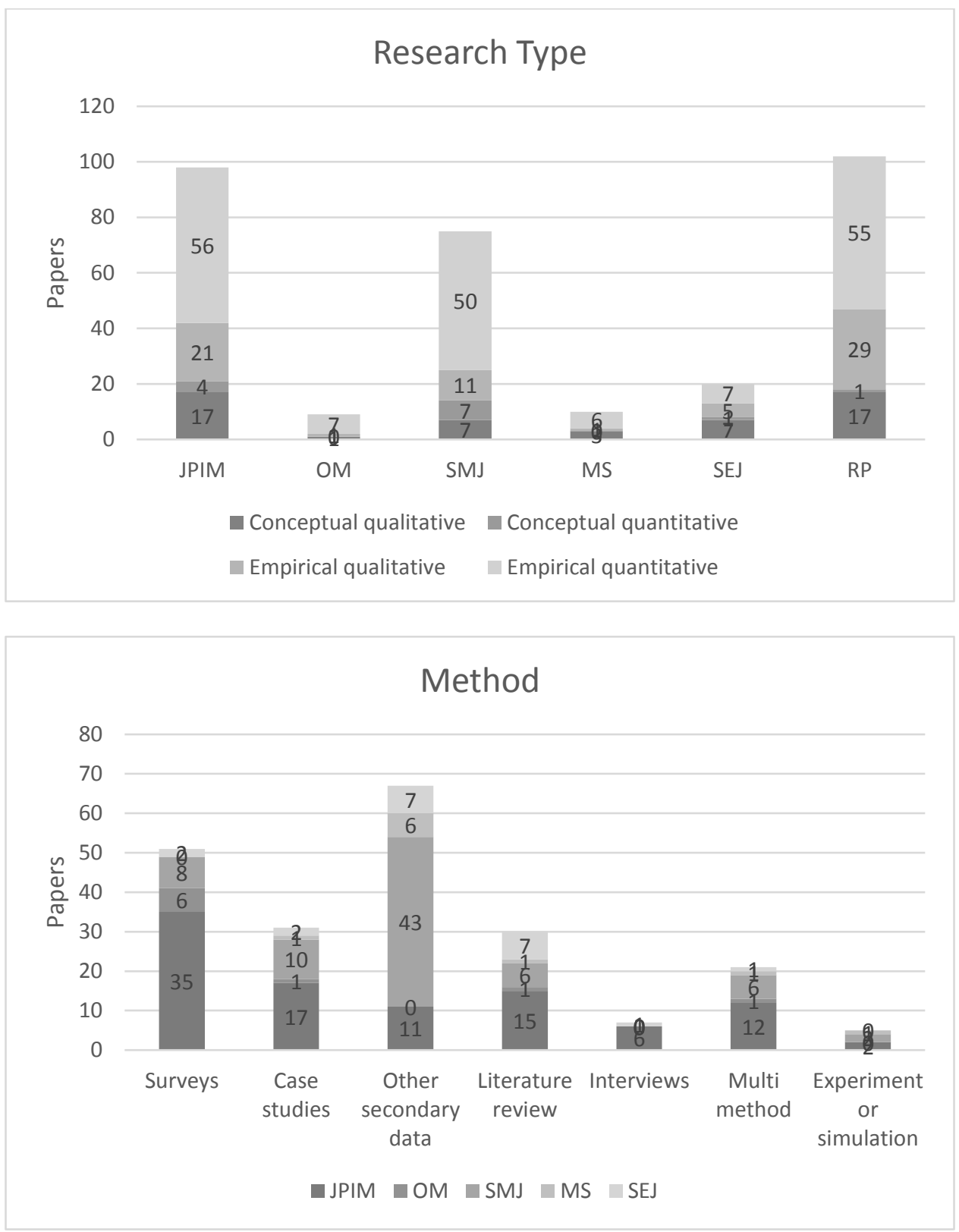
Figure 3: Ansoff's Growth Matrix

\begin{tabular}{c|c|c|}
\cline { 2 - 3 } Development & $\begin{array}{c}\text { Launch } \\
\text { Management }\end{array}$ & $\begin{array}{c}\text { Business } \\
\text { Development }\end{array}$ \\
\cline { 2 - 3 } & \multicolumn{1}{c|}{$\begin{array}{c}\text { Existing } \\
\text { customers } \\
\text { Management }\end{array}$} & Sales /Marketing \\
\cline { 2 - 3 } & $\begin{array}{c}\text { New } \\
\text { customers }\end{array}$
\end{tabular}

